\title{
O câmbio como ferramenta de política econômica e os efeitos sobre a indústria brasileira: Uma análise histórica
}

Resumo: O objetivo deste estudo foi analisar o papel da política cambial brasileira e a sua influência sobre o setor industrial. Pode-se constatar que ocorre no Brasil uma desindustrialização como perda de participação do setor industrial no PIB brasileiro. A liberalização comercial e financeira abrupta nos anos 90, combinada a uma política cambial sobrevalorizada nos anos 2000, em decorrência do fenômeno Doença Holandesa no Brasil, podem estar afetando negativamente o setor industrial. Mesmo que os governos Lula e Dilma tenham criado políticas industriais para fomentar o setor e mesmo que tenha sido válida, contudo não foi suficiente, diante de um ambiente macroeconômico desfavorável, principalmente em função do câmbio apreciado e de juros altos que inibem os investimentos necessários para o crescimento da indústria. Em decorrência disso, a indústria brasileira perdeu participação nas exportações brasileiras e o setor industrial apresentou baixo dinamismo tanto externo quanto interno, uma vez que houve uma crescente importação de produtos industriais.

Palavras-chaves: Taxa de câmbio; Desindustrialização; Doença holandesa

\begin{abstract}
The aim of this study was to analyze the role of the Brazilian exchange rate policy and its influence on the industrial sector. It can be seen occurring in Brazil de-industrialization and loss of market share of the industrial sector in the Brazilian GDP. The rapid trade and financial liberalization in the 90s, combined with an overvalued exchange rate policy in the 2000s as a result of Dutch Disease phenomenon in Brazil, may be adversely affecting the industry. Even if Lula and Dilma governments, have created industrial policies to promote the sector and even if it was valid, but it was not enough in the face of an unfavorable macroeconomic environment, mainly due to the appreciated exchange rate and high interest rates that inhibit the necessary investments to the growth of industry. As a result, the Brazilian industry lost share in Brazilian exports and the industrial sector showed low dynamism both external and internal, since there was a growing import of industrial products.
\end{abstract}

Keywords: Exchange rate; Deindustrialization; Dutch disease

Área de submissão: Globalização e competitividade regional

Classificação JEL do Trabalho: F00. F10. F14. 


\section{INTRODUÇÃO}

A globalização da produção possibilitou aos países uma intensa movimentação de capitais estrangeiros em busca de maiores rentabilidades e importantes fontes para o crescimento da economia brasileira. Contudo, a fuga de capitais origina a diminuição das reservas cambiais pressionando as taxas de câmbio e a economia interna (CAPACLE CORREA; LIMA, 2006). Dessa forma, através da política cambial, o Estado atua no sentido de regular o funcionamento da economia no que se refere à estabilidade das taxas de câmbio e ao equilíbrio no balanço de pagamentos (BACEN, 2014).

Para Trevisan (2004) a taxa de câmbio pode ser definida como a medida de conversão da moeda de um país por moeda de outro, é um dos preços fundamentais da economia, uma vez que permite avaliar os preços, expressos em moeda nacional, dos bens e serviços produzidos no exterior, afetando o setor externo, a inflação, o crescimento da produção e outras variáveis economicamente relevantes.

Existem dois tipos de taxas de câmbio conforme Carneiro (2013), a taxa nominal e a taxa real. A taxa de câmbio nominal representa o preço de uma moeda em termos de outra, isto é, quantas unidades de uma determinada moeda em troca de uma unidade da outra, a taxa será definida como o número de unidades de moeda doméstica necessárias para adquirir uma unidade da estrangeira, de modo que um aumento na taxa significa uma depreciação cambial nominal doméstica, e sua redução significa uma apreciação. As taxas de câmbio têm papel central no comércio internacional porque elas nos permitem comparar os preços dos bens e serviços produzidos em países diferentes. Assim os indivíduos e empresas utilizam as taxas de câmbio para traduzir os preços estrangeiros em termos da moeda doméstica (KRUGMAN e OBSTFELD, 2001).

Afirmam Baumann, Canuto e Gonçalvez (2004) que a evolução nominal da taxa de câmbio e de preços locais e externos afetam a competividade-preço de modo setorialmente desigual, se ocorrer, no período, divergência entre os movimentos de preços relativos no país e no exterior. Assim, alterações na taxa de câmbio podem gerar efeito nos preços, uma vez que influem as decisões de oferta e demanda na economia, e consequentemente as importações e exportações. Neste sentido, uma depreciação cambial, significa uma redução dos preços dos bens nacionais em comparação com os estrangeiros e com isso a indústria doméstica passa a gerar competitividade frente aos concorrentes internacionais. Por outro lado, uma apreciação da taxa de câmbio representa produtos nacionais mais caros que os dos concorrentes externos, 
ocasionando perda de competitividade da indústria nacional, que por sua vez, impulsiona as importações.

Neste sentido, o Estado pode utilizar a política cambial como mecanismo para fomentar o comércio do país com outros países. A importância de tal instrumento é determinada pelo grau de abertura da economia do país ao exterior, bem como pela sua importância no tocante ao crescimento e à estabilização das atividades econômicas internas (TREVISAN, 2004).

A indústria é o setor que possui elevado potencial para alavancar o desenvolvimento econômico e social de uma nação, especialmente, de países em estágio intermediários de desenvolvimento como o Brasil. Atualmente o Brasil possui uma base de produção industrial diversificada, compreendendo 27 atividades industriais, desde a indústria de minério, de petróleo, química e alimentícia, como também produtos intensivos em tecnologia, tais como a indústria aeronáutica, elétrica, automobilística e farmacêutica (IBGE, 2011).

Contudo, com relação à produtividade, a indústria do Brasil não manteve crescimento nos últimos 40 anos. Depois de crescer $9 \%$ por ano na década de 1970, a indústria perdeu impulso, e a taxa média entre 1980 e 2010 caiu para 1,3\% ao ano (FONSECA, 2012). Além disso, para Bonelli e Pinheiro (2012) numa perspectiva de longo prazo, fica claro que no Brasil a indústria vem reduzindo sua participação no PIB - Produto Interno Bruto, após atingir um pico de participação de 23\% do PIB no período entre 1974 e1976, a indústria chegou ao triênio 2009-2011 respondendo por apenas 16\% do PIB, caracterizando uma desindustrialização brasileira ocorrida nos últimos anos.

Sendo assim, resta indagar: a perda de participação do setor industrial no PIB brasileiro é reflexo da política cambial adotada nos últimos anos? Quais as possíveis causas da desindustrialização brasileira? Que medidas adotar para fomentar o setor industrial à competitividade e impulsionar a economia do país novamente?

Diante deste cenário e através de uma investigação empírica, o presente trabalho possui como objetivo principal analisar o papel da política cambial brasileira e a sua influência sobre o setor industrial.

O trabalho encontra-se assim dividido, além dessa introdução: na seção 2 apresenta-se uma breve revisão bibliográfica da política cambial brasileira a partir da década de 30 . Na seção 3 se faz uma discussão sobre a política cambial a partir dos anos 2000 e os reflexos sobre o desempenho do setor industrial. Por último, a seção 4 apresenta as considerações finais. 


\section{POLÍTICAS CAMBIAIS NO BRASIL}

Desde de 1930, com a crise do setor exportador, a política cambial por meio da substituição das importações se destacou como uma das principais ferramentas de incentivo a industrialização. Estudiosos da Comissão Econômica para América Latina e Caribe - CEPAL, Celso Furtado e Raúl Prebisch, foram os responsáveis pela teoria dos choques adversos e explicam esse momento. Segundo os autores, as crises vivenciadas pelo setor exportador deram condições para que a economia se voltasse para o mercado interno, com isso o setor industrial obteve impulso no país (FONSECA, 2009).

O governo de Getúlio Vargas (1930-1945) optou por defender a manutenção da renda do setor agroexportador, seja por meio do financiamento de estoques com empréstimos externos ou com expansão de crédito, como mecanismo de assegurar emprego e renda ao setor com representatividade na economia e assim conter os efeitos da crise. De acordo com Furtado (2003) a combinação do encarecimento brusco das importações (consequência da depreciação cambial), com a existência de capacidade ociosa em algumas das indústrias que trabalhavam para o mercado interno e ao fato de que já existia no país um pequeno núcleo de indústrias de bens de capital, explica a rápida ascensão da produção industrial, que passa a ser o fator dinâmico principal no processo de criação da renda.

Dessa forma, o governo passou a defender a política de substituição de importações, com o objetivo de importar máquinas e equipamentos necessários para o processo de industrialização brasileira, caracterizada pela manipulação da taxa de câmbio e o controle seletivo das importações.

Em 1948, com a criação da Comissão Econômica para América Latina (CEPAL), pesquisadores realizaram estudos com objetivo de entender os entraves para o crescimento econômico dos países da América Latina. Identificaram que para superar o subdesenvolvimento, o Estado deveria incentivar a industrialização e em decorrência dessa escola, as décadas de 50 e 60 foram influenciadas por esse pensamento.

Diante disso, o governo Juscelino Kubitschek (1956-1961) implantou um programa de investimentos jamais visto no país, conhecido como Plano de Metas. Foram investimentos importantes em infraestrutura e paralelo a isso, criaram condições para que a indústria brasileira se fortalecesse.

Ao final dos anos 60, conhecido como milagre econômico brasileiro (1968-1973), possibilitou a indústria se consolidar muito em função de uma política cambial que favorecia as importações de equipamentos e matérias-primas, pela tarifa aduaneira protecionista, pelos 
favores cambiais e financeiros ao capital estrangeiro e pela presença do Estado como empresário para os setores de infraestrutura e de linhas de financiamento via Banco Nacional do Desenvolvimento Econômico (BNDE) (SUZIGAN, 1978).

Neste período é possível observar, conforme o Quadro 1, a evolução do crescimento experimentado pelo Brasil, antes e durante o milagre econômico. A taxa média de crescimento do PIB, foi de $11,1 \%$ no período $1968-1973$, frente a 4,2\% no período anterior ao milagre 19641967.

Quadro 1: Brasil: Comparação de Indicadores Macroeconômicos: 1964-1967 e 1968- 1973

\begin{tabular}{|l|cc|}
\hline \multicolumn{1}{|c}{ Indicadores selecionados } & $\begin{array}{c}\text { Média } \\
\text { 1964-1967 }\end{array}$ & $\begin{array}{c}\text { Média 1968- } \\
\text { Taxa de crescimento do PIB (\%) }\end{array}$ \\
Inflação (IGP, \%) & 4,2 & 11,1 \\
Taxa de crescimento das exportações em US\$ (\% a.a.) & 45,5 & 19,1 \\
Taxa de crescimento das importações em US\$ (\% a.a.) & 2,7 & 24,6 \\
Saldo da Balança Comercial (em US\$ milhões) & 412 & 27,5 \\
Dívida Externa Líquida/Exportação de Bens em \% & 2,0 & 0 \\
Saldo do Balanço de Pagamentos (em US\$ milhões) & $-13,8$ & 1,8 \\
\hline
\end{tabular}

Fonte: Veloso, Villela e Giambiagi (2008, p.225)

As exportações saltaram uma taxa média de crescimento ao ano de 4,1\% entre 19641967 para 24,6\% no período 1968-1973, paralelo a isso, as importações também cresceram, passando de 2,7\% para uma taxa média de 27,5\% ao ano 1968-1973. Apesar de apresentar queda no saldo da balança comercial no milagre econômico, se pode-se observar um crescimento do saldo do balanço de pagamentos que passou a ser positivo no período 19681973.

Paralelo a isso, o crescimento experimentado no milagre econômico brasileiro, foi acompanhado de um forte endividamento externo, ou seja, se deu baseado com poupança externa. Assim, a fragilidade do país tornou-se evidente em 1982, após a moratória mexicana. A partir daí, o Brasil deixou de ser receptor e tornou-se emissor de capitais, ou seja, os credores passaram a exigir o pagamento dos empréstimos concedidos no período anterior. Intensificouse a desvalorização da moeda e o país passou a apresentar taxas cada vez mais elevadas de inflação e baixas taxas de crescimento (BAHRY e PORCILE, 2004). 
Além disso, em 1973 ocorreu o primeiro choque do petróleo, um aumento expressivo do preço do barril, que por sua vez, elevou o preço dos insumos energéticos e de matériasprimas o que provocou aumento dos custos industriais, ocasionando uma resseção internacional. Segundo Kodja (2009) em represália ao apoio norte-americano à Guerra do Yom Kipur, a OAPEC (Organization of Arab Petroleum Exporting Countries) "determinou” o embargo à distribuição de petróleo, entre 1970 e 1974 e o preço do petróleo aumentou de US\$ 1,8 para US\$ 10 por barril, um aumento de $455 \%$.

Em resposta à crise do petróleo, o governo brasileiro lança em 1975 o II Plano Nacional de Desenvolvimento (PND), com objetivo de investir e incentivar alternativas de energias renováveis, entre outras ações, inclusive foi nesse momento que foi criado o Programa Nacional do Álcool (Proálcool), como alternativa para substituição de combustíveis derivados de petróleo por álcool.

Porém, para pôr em prática o II PND, foi necessário que o Brasil captasse recursos financeiros externos, aumentou a oferta de moeda e por sua vez, pressionou o câmbio alto e como consequência, isso fez com que aumentasse a dívida do país, conforme o Gráfico 1. O endividamento brasileiro saltou de US\$ 2,4 bilhões em 1972 para US\$ 8,6 bilhões em 1979. Com o segundo choque do petróleo, veio a recessão internacional e com isso a captação de recursos externos caiu para US\$ 4,8 bilhões em 1980.

Vale ressaltar que diante das medidas adotadas no II PND e a necessidade de pôr em prática as ações do plano, é possível observar que há uma mudança na composição do capital tomador, passando a necessidade do setor público demandar mais recursos externos em comparação com o setor privado, com objetivo de fomentar a economia brasileira.

Em 1972 o setor privado era responsável por 75,1\% do capital tomador de empréstimo, enquanto que o setor público correspondia por 24,9\%. Contudo, justamente a partir de 1975, há uma mudança de panorama e o setor público passa a ser o principal responsável pelo endividamento brasileiro. Conforme Bresser-Pereira (2012) o crescimento com poupança externa, implica em médio prazo, aumento da fragilidade financeira do país e, em seguida, crise de balanço de pagamentos que em medida aprecia o câmbio. 
Gráfico 1: Estrutura de empréstimo em bilhões US\$, por capital tomador para o período 1972-1980

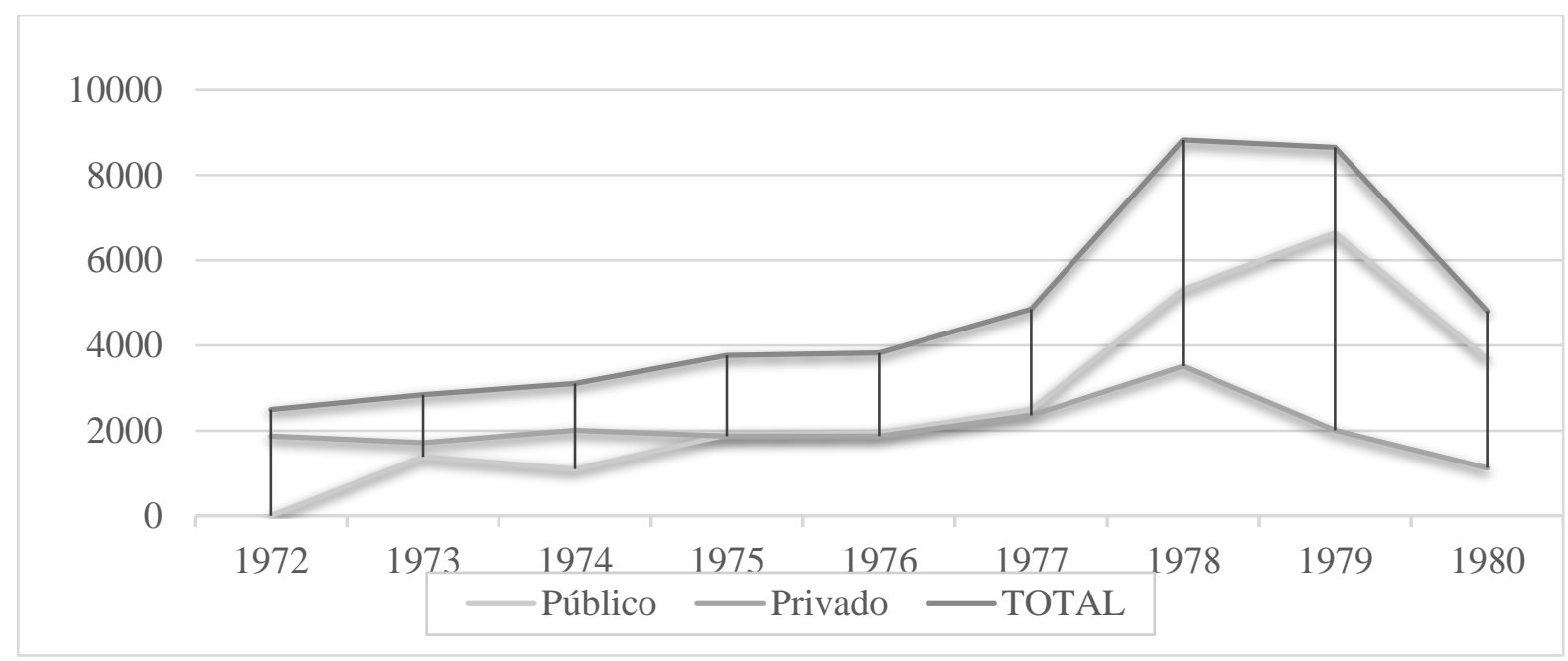

Fonte: Dados compilados de DAVIDOFF CRUZ (1982, p.73)

Campos (1999) relata que com a retirada do setor privado da capitação por recursos externos e consequentemente com a queda dos investimentos diante da recessão internacional, ocasionada pelo choque do petróleo, além das necessidades de recursos para o II PND, o governo brasileiro também se viu obrigado a aumentar a participação no endividamento em função dos desequilíbrios na conta de mercadorias e serviços produtivos, bem como do pagamento de juros e serviços que exigiam a entrada maciça de divisas.

Em agosto de 1982, o México declara moratória e após as eleições de novembro, o Brasil passa a fazer parte do grupo de devedores problemáticos, recorrendo ao FMI. O aumento das taxas de juros internacionais e, consequentemente, o crescimento repentino do ônus da dívida são as causas mais imediatas da deficiência de divisas externas no caso brasileiro (BAHRY e PORCILE, 2004).

É possível observar nesse período, que há um crescente endividamento capitaneado pelo setor público, obtidos junto ao sistema financeiro internacional e que enquanto as economias desenvolvidas estavam em recessão, o governo brasileiro optou por estimular o crescimento através do endividamento externo, contudo, não esperava que o segundo choque do petróleo e a crise dos juros desencadeados no México, pudessem por fim as medidas que foram adotadas no II PND.

A década de 80 ficou conhecida como "A Década Perdida”, o país passou por uma recessão, no sentido de conter a crise da dívida externa e o aumento da inflação. Além disso, conforme Campos (2004), houve uma redução da arrecadação tributária e estatização da dívida 
externa, que limitou os aportes fiscais para cobrir as dificuldades financeiras das estatais e ampliou-se a interferência federal na gestão das empresas, utilizando-se preços e tarifas públicas irreais em políticas macroeconômicas de combate à inflação.

Conforme a Tabela 1, a década de 70 em função do milagre econômico, possibilitou ao país crescer em ritmo acelerado, com uma taxa média de 8,63\%. Contudo, no decorrer da década de 80, o país estagnou e o Produto Interno Bruto (PIB) cresceu apenas 1,57\%, devido à crise da dívida externa e a crise que sucedeu com o fim do modelo de desenvolvimento capitaneado pelo Estado.

Tabela 1 - Crescimento do PIB brasileiro em três décadas em \%

\begin{tabular}{c|cc} 
Periodo & PIB & PIB por habitante \\
\hline $1971-1980$ & $8,63 \%$ & $5,72 \%$ \\
$1981-1990$ & $1,57 \%$ & $-0,37 \%$ \\
$1991-2000$ & $2,65 \%$ & $1,11 \%$
\end{tabular}

Fonte: Ipeadata

Além disso, conforme Campos (1997, p. 109) “a inflação no país atingiu níveis altíssimos, ao final do ano de 1989, a inflação foi de 1.782,89\% (IGP-DI/FGV), e ao primeiro trimestre do ano de 1990 corresponderam, respectivamente, as seguintes taxas inflacionárias: 56,11\% (janeiro), 72,78\% (fevereiro) e 84,32\% (março)."

Diante da crise mundial na década de 80 , marcada por baixo crescimento com elevadas taxas de inflação, em 1989 ocorre o Consenso de Washington, liderado por instituições financeiras internacionais como o Fundo Monetário Internacional (FMI), Banco Mundial e o Departamento do Tesouro dos Estados Unidos. Segundo Bresser-Pereira (1990) o Consenso de Washington formou-se a partir da crise do consenso keynesiano e da correspondente crise da teoria do desenvolvimento econômico.

Ainda segundo o autor, o consenso define as causas da crise latino-americana como sendo: a) o excessivo crescimento do Estado, traduzido em protecionismo, excesso de regulação e empresas estatais ineficientes e um número excessivo; e b) o populismo econômico, definido pela incapacidade de controlar o déficit público e de manter sob controle as demandas salariais tanto do setor privado quando do setor público.

Conforme Batista (1994) as principais diretrizes de política econômica que emergiram com o consenso foram: 1) disciplina fiscal; 2) priorização dos gastos públicos; 3) reforma tributária; 4) liberalização financeira; 5) regime cambial; 6) liberalização comercial; 7) 
investimento direto estrangeiro; 8) privatização; 9) desregulação; 10) direito de propriedade intelectual.

Em resumo, o consenso de Washington ficou marcado por uma linha ideológica chamada de neoliberalismo e está pressupunha que para as economias latino-americanas retornassem ao desenvolvimento, seria necessária uma redução do Estado, através de um ajuste fiscal e adoção de políticas econômicas em que o mercado desempenhe o papel fundamental, liberalizando a economia e permitindo privatizações.

Diante disso, já no início da década de 90, o governo Collor passou a adotar as medidas fundamentadas no consenso de Washington. Observa-se uma ruptura sobre o modo de conduzir a economia brasileira, que passa a predominar o desenvolvimento sobre a perspectiva do pensamento neoliberal, pondo um fim a política de proteção à indústria local (substituição das importações), imposta desde a década de 30.

Desse modo, conforme Kupfer (1998) acontece no Brasil no decorrer da década de 90, uma reestruturação da indústria brasileira, impulsionada pelo processo de liberalização da economia apoiado no tripé comercial, desregulamentação da economia, desestatização e a estabilização monetária a partir de 1994.

Com relação às privatizações, iniciaram-se no governo Collor, através do Programa Nacional de Desestatização (PND) em 1990, mas com o impeachment de Collor em 1992, diante das denúncias de corrupção, assume Itamar Franco (1992-1994) como presidente interino, tendo como Ministro da Fazenda Fernando Henrique Cardoso (FHC), que posteriormente viria a ser presidente (1995-2002) e foi no governo FHC que se pode visualizar com mais evidência as privatizações em diversos setores da economia.

Um dos principais objetivos das privatizações tem sido o de proporcionar uma melhoria na qualidade dos serviços prestados à sociedade brasileira, através de aumento de investimentos a serem realizados pelos novos controladores. (SOARES, 2008)

Ao todo, conforme dados do Banco Nacional do Desenvolvimento Econômico e Social (BNDES), é possível verificar no Gráfico 2, a dimensão da privatização no Brasil ao longo do período (1991-2002). A privatização alcançou no período um total de US\$ 105,3 bilhões, somente o governo $\mathrm{FHC}$, foi responsável por $88,8 \%$ das privatizações.

De acordo com dados do Banco Nacional do Desenvolvimento Econômico e Social (BNDES), os principais setores direcionados com as vendas das privatizações ao longo do período, foram: energia elétrica (31\%), telecomunicações (31), mineração (8\%), siderúrgica (8\%), petróleo e gás $(7 \%)$, juntos representam $85 \%$ dos investimentos, um total de US\$ 80,7 bilhões. 


\section{Gráfico 2 - Privatização no Brasil em US\$ bilhões no período 1991-2002}

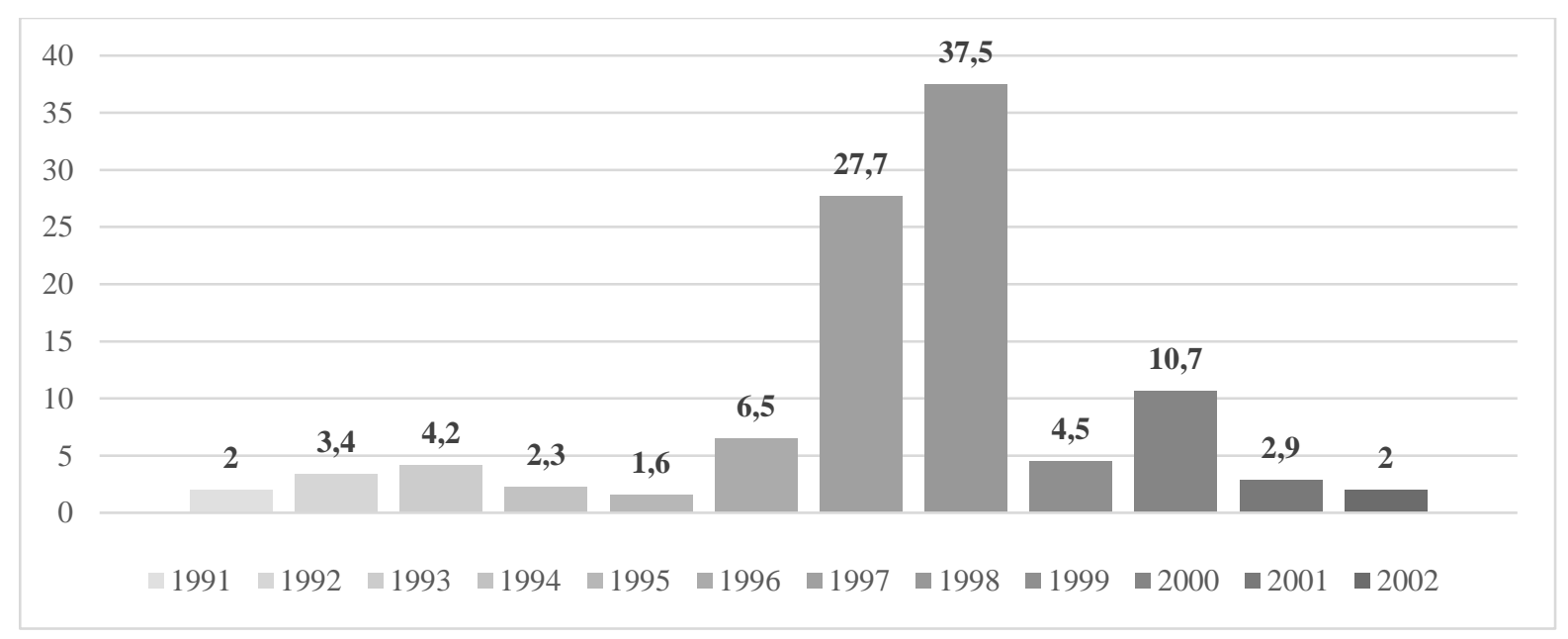

Fonte: BNDES

Segundo Pinheiro (1999) com as grandes vendas de 1997-1998, o Brasil foi capaz de atrair elevados montantes de investimento direto estrangeiro, que ajudaram a financiar os altos déficits em conta corrente, e de evitar a explosão da dívida pública, a despeito dos crescentes déficits públicos registrados desde 1995. Contudo, de acordo com Gennari (2001) é relevante levar em conta que apesar da expressividade do montante dos investimentos diretos estrangeiros no Brasil, principalmente nos anos 1997 e 1998, não surtiram grande alteração na taxa de investimento no país, que passou de 15,2\% em 1991, para apenas 17,2\% em 1999.

Ainda no governo Itamar Franco, sob responsabilidade de Fernando Henrique Cardoso como Ministro da Fazenda, é lançado o Plano Real, com objetivo de estabilizar a economia brasileira que vinha sofrendo com altos índices de inflação. De acordo com Pinheiro, Giambiagi e Gostkorzewicz (1999) por causa do impacto da taxa de câmbio sobrevalorizado no Plano Real, o plano de estabilização econômica baseou-se, principalmente, na sucessão de etapas que precederam a sua implementação: a adoção de medidas destinadas a buscar o equilíbrio das contas públicas; o estabelecimento de uma unidade de conta (URV) para alinhar os preços relativos da economia; e a conversão dessa unidade de valor na nova moeda estável da economia, o real.

As políticas adotadas do Plano Real, somadas à continuidade da abertura do país aos capitais estrangeiros e a manutenção de um diferencial elevado de taxas de juros permitiram que a moeda nacional ganhasse valor frente ao dólar. A princípio, o governo brasileiro adotou uma paridade máxima entre o real e o dólar, como equivalente à R $\$ 1=\mathrm{US} \$ 1$. O limite inferior não foi num primeiro momento oficialmente fixado. Entre julho e setembro de 1994 não houve 
qualquer intervenção no mercado de câmbio que sofreu, de fato, uma apreciação, caindo para algo em torno de $\mathrm{R} \$ 0.85 / \mathrm{US} \$ 1$. Tendo em vista que as consequências da apreciação da moeda afetaram a balança de transações correntes, em setembro o Banco Central realizou sua primeira intervenção no mercado de câmbio e anunciou, em outubro, informalmente, que estaria disposto a comprar dólares a uma taxa mínima de $\mathrm{R} \$ 0.82 / \mathrm{US} \$ 1$, e vender a uma taxa máxima de R\$0.86/US\$1. Estava assim caracterizado um sistema 'informal' de bandas cambias tendo apenas um limite superior oficialmente determinado, mas um limite inferior implicitamente assumido, haja vista o comportamento da autoridade monetária (SOARES; PINTO, 2008).

Desta forma, ficou estabelecido o regime da taxa de câmbio por meio de bandas cambiais, que caracterizou o controle da taxa com limites superiores e inferiores, podendo a taxa de câmbio flutuar dentro desse limite. Conforme Soares (2006) as medidas surtiram efeito, a taxa de câmbio foi mantida não só dentro da banda estabelecida, mas também dentro do esquema de prefixação cambial informalmente definido pelo Banco Central, dessa forma, foi estabelecido um regime de desvalorização da taxa de câmbio, porém sem a assunção de compromissos pelos atores monetários.

Contudo, as crises que se sucederam a partir de 1995, como as crises do México, a crise da Ásia em 1997 e da Rússia em 1998, criaram um clima de incertezas no mercado financeiro internacional sobre as economias emergentes. Mesmo que o governo brasileiro tenha aumentado a taxa de juros e utilizado da venda de reservas internacionais para conter a crise houve fuga de capital estrangeiro. Além disso, problemas internos, tais como a falta de comprometimento por parte do governo com o equilíbrio fiscal, a supervalorização cambial e a eleição presidencial de outubro de 1998, desestabilizaram ainda mais a economia brasileira (SOARES, 2006).

Em dezembro de 1998, o Fundo Monetário Internacional (FMI) e países industrializados anunciaram um pacote de ajuda ao Brasil de US\$ 41,5 bilhões. A partir disso, o governo brasileiro, em janeiro de 1999, modificou sua política cambial para um regime de câmbio flutuante, premido a isso pelos ataques especulativos que, nos últimos meses, reduziram suas reservas cambiais de US\$ 75 bilhões, em abril de 1998, para cerca de US\$ US\$ 30 bilhões, quando ocorreu a liberação do câmbio de 15 de janeiro de 1999 (SILVA, 2002).

Dessa forma, com a implantação do regime de câmbio flutuante no Brasil, a economia logrou ajustes substanciais no balanço de pagamentos e ao mesmo tempo foi capaz, através de uma política monetária guiada por metas inflacionárias, de manter a inflação em níveis aceitáveis. 
Vale ressaltar que além da manipulação da taxa de câmbio, que foi desvalorizada entre o período de 1992-1998, também houve uma reforma comercial no sentido da eliminação dos controles quantitativos e administrativos sobre as importações somado a proposta de redução tarifária. A tarifa nominal média de importação, que era 40\% em 1990, foi reduzida e atingiu com 13\% seu nível mais baixo em 1995 (GENNARI, 2001).

Ao final da década de 90, a liberalização comercial possibilitou ao país um salto na importação de produtos mais baratos e com qualidade aos similares produzidos no país. Por outro lado, impôs à indústria local obter ganhos de eficiência produtiva de forma a responder rapidamente à pressão da concorrência internacional. Entretanto, a defasagem de capacitação herdada dos anos de estagnação (anos 80), implicou em enorme pressão pela modernização dos procedimentos produtivos, sob o risco da própria sobrevivência para as empresas (KUPFER, 1998).

O crescimento do comércio entre 1990-2014, passou de US\$ 52,1 bilhões em 1990, para US\$ 454 bilhões em 2014, um crescimento expressivo de $771 \%$ no período. Contudo, a manipulação da taxa de câmbio combinado com uma queda nas tarifas de importações, tornase evidente o crescimento das importações na década de 90. Conforme Pinheiro, Giambiagi e Gostkorzewicz (1999) a queda do valor das exportações no período 1995-1999 foi decorrente das crises financeiras internacionais, da queda das cotações das principais commodities no mercado internacional e do desaquecimento da economia mundial.

\section{POLÍTICAS CAMBIAIS RECENTES NO BRASIL}

A partir dos anos 2000, conforme o Gráfico 3, nota-se um boom das exportações brasileiras, tendo em vista uma crescente participação dos produtos primários. Em contrapartida, houve uma crescente importação de produtos industriais, decorrente de uma política cambial pautada na apreciação cambial a partir entre 2003-2008. Segundo BresserPereira (2015) o governo Lula (2003-2010) recebeu do governo anterior uma taxa de câmbio altamente depreciada, mas foi deixou que ela se apreciasse nos oito anos desse governo. Em seu governo houve um breve período de bom crescimento empurrado pelo aumento do preço das commodities, mas assim que os importadores de manufaturados se organizaram para importar, (o que demora em média três anos), as empresas industriais, que haviam deixado de exportar no começo do governo, mas ainda conservavam o mercado interno, o perderam para os importados. 


\section{Gráfico 3 - Evolução das exportações e das importações em (US\$ bilhões) e da taxa de câmbio real* no Brasil - 1990-2014}

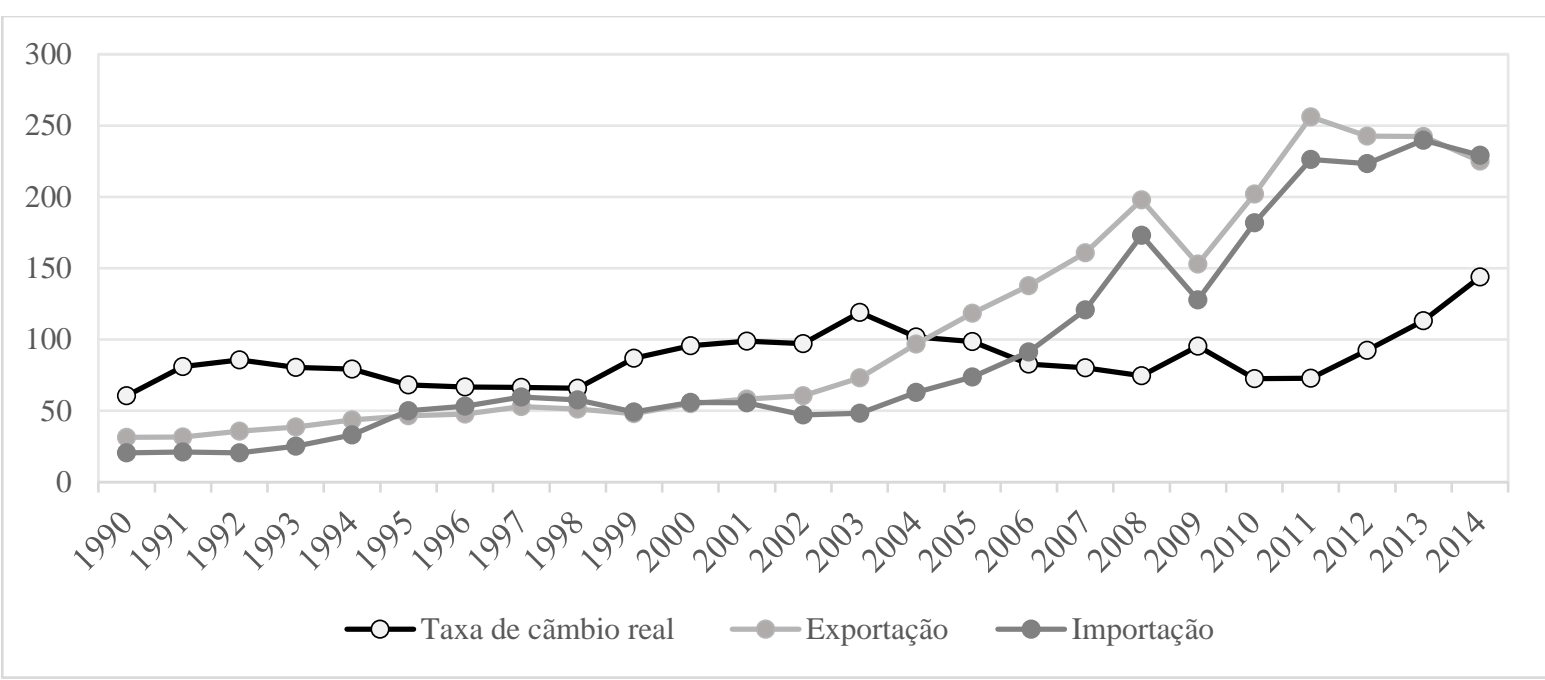

Fonte: Ipeadata

Nota: * Taxa de câmbio real referente aos meses de janeiro entre 1990-2014. Calculada pelo expurgo do Índice Nacional de Preços ao Consumidor (INPC) e dos Índices de Preços por Atacado (IPAs) dos 16 mais importantes parceiros comerciais do Brasil da série nominal de taxa de câmbio (R \$ US\$), ponderada pela participação de cada parceiro na pauta do total das exportações brasileiras em 2001.

Chama atenção a pujança das exportações brasileiras a partir de 2003, conhecido como o boom das exportações de commodities, impulsionando pelo crescimento do consumo mundial, acelerado pela demanda do mercado chinês. Paralelo a isso, o efeito do aumento dos preços das commodities, contribuiu para que o saldo da balança comercial apresentasse saldo da balança comercial ao longo do período.

Reflexo de uma política cambial no governo Lula, pautado na apreciação cambial com objetivo de assegurar a inflação, afetou de forma desproporcional a indústria brasileira e estimulou as importações de produtos industriais, como se pode ver no Gráfico 4. Em 2003, o saldo da balança comercial de produtos industriais, encontrava-se positivo em US\$10,4 bilhões, crescimento que foi acompanhado até 2006 quando atingiu o montante de US\$20,3 bilhões. Contudo, entre 2003-2014 as importações cresceram 358\%, enquanto que às exportações apenas $115,9 \%$, como resultado, a partir de 2007, a balança comercial de produtos industriais vem apresentando crescente déficit comercial e ao final do período fechou ao saldo negativo de um montante de US\$ 109 bilhões em 2014. 


\section{Gráfico 4 - Balança comercial brasileira de produtos industriais em bilhões US\$}

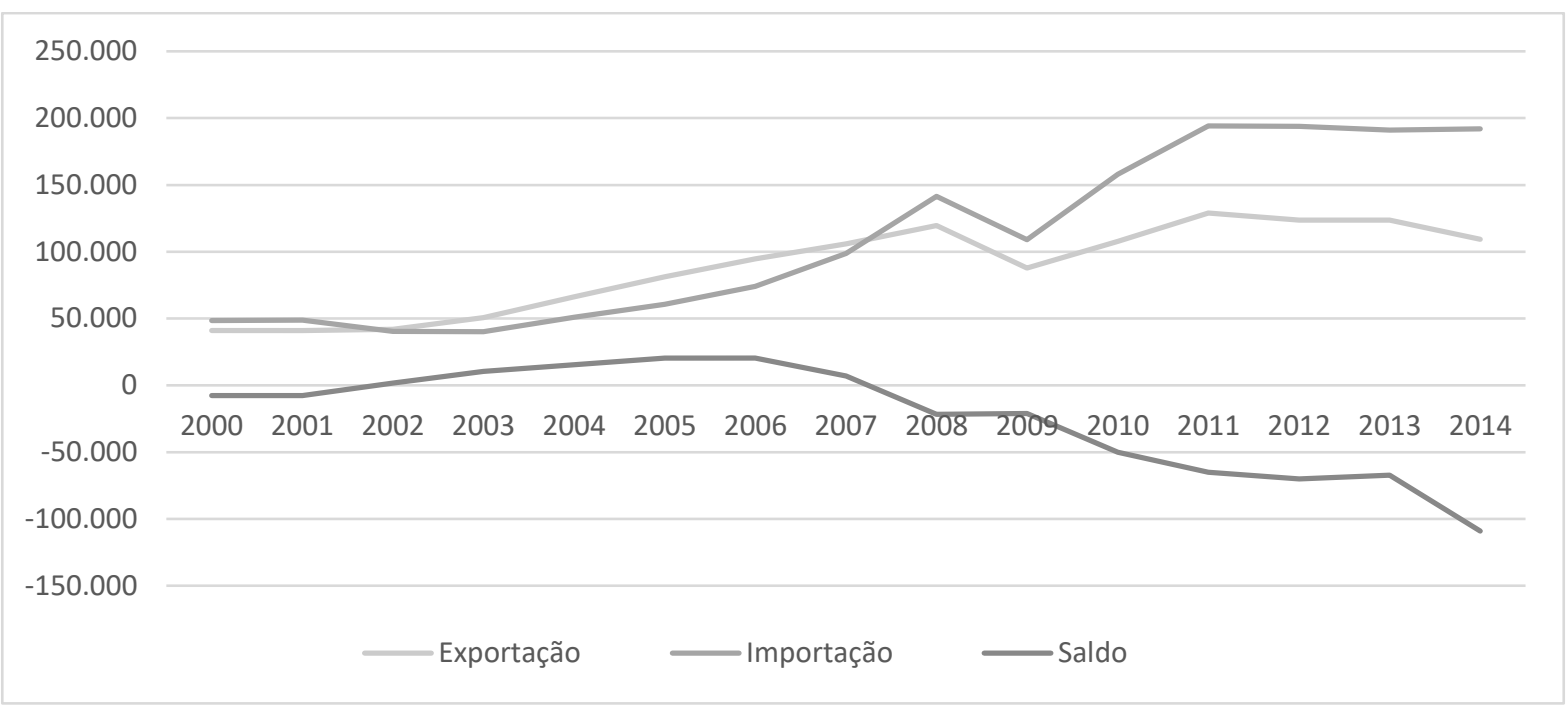

Fonte: MIDIC

Em consequência disso, conforme o Gráfico 5, a participação da industrial geral e a participação da indústria de transformação em relação ao Produto Interno Bruto - PIB brasileiro, tem perdido força a partir dos anos 2000. A queda na variação é mais visível para a indústria de transformação, que em 2000 representava 14,92\%, alcançou 15,59\% em 2004, mas logo em seguida perdeu força e vem apresentando uma queda acentuada e em 2012 chegou ao patamar mais baixo do período, com uma participação de apenas 10,99\%, houve uma pequena reação em 2013, mas ao longo do período a queda foi $25 \%$.

\section{Gráfico 5 - Participação da Indústria geral e da indústria de transformação no PIB brasileiro}

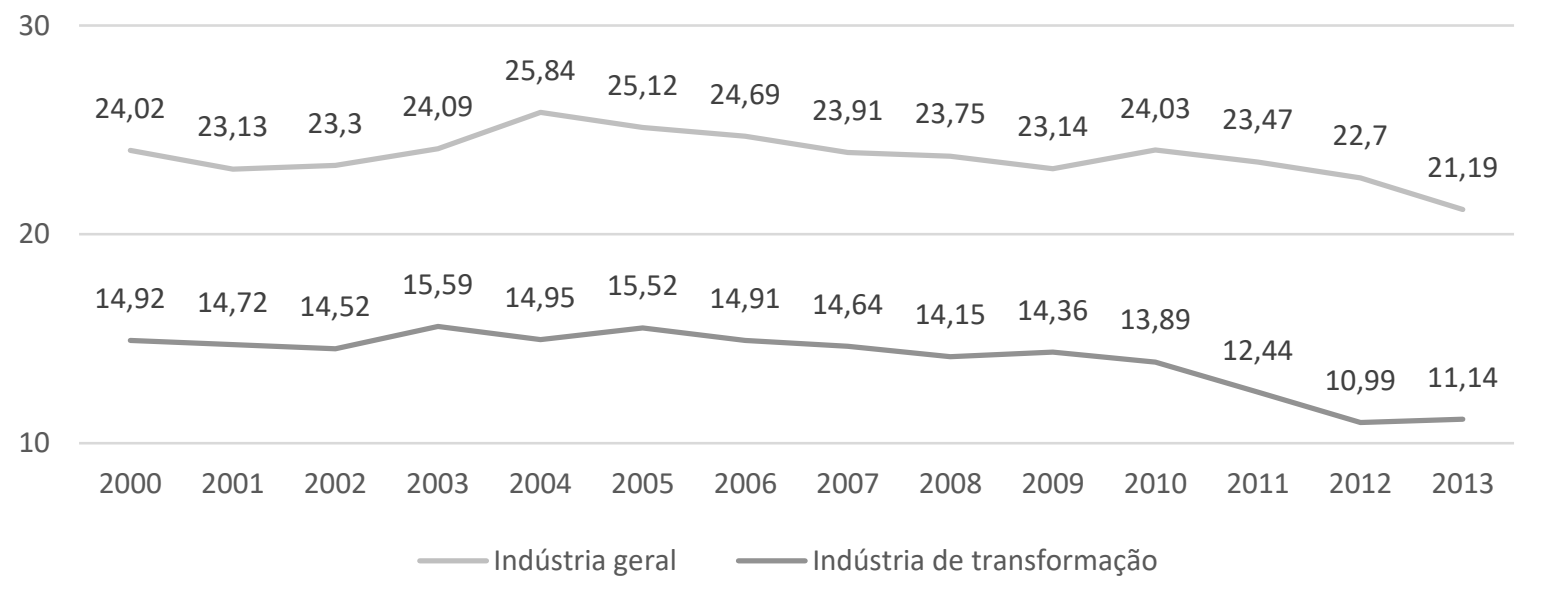

Fonte: IBGE, Contas Nacionais Trimestrais 
Diante deste cenário da perda de participação da indústria no PIB brasileiro, é possível concluir que o país está se desindustrializando, por sua vez, pode impactar profundamente no crescimento e desenvolvimento da economia do país, através da queda na geração do emprego e renda. De acordo com dados da FIESP (2015), em 2014, foi a primeira vez desde 2002 que as demissões da indústria de transformação superaram as admissões no Brasil, no acumulado do ano. Isso provocou a primeira redução líquida de emprego formal do setor nos últimos 13 anos, que representa uma perda líquida de cerca de 164 mil empregos formais na indústria em 2014.

\section{Gráfico 6 - Geração líquida de emprego da indústria de transformação entre 2002 e 2014}

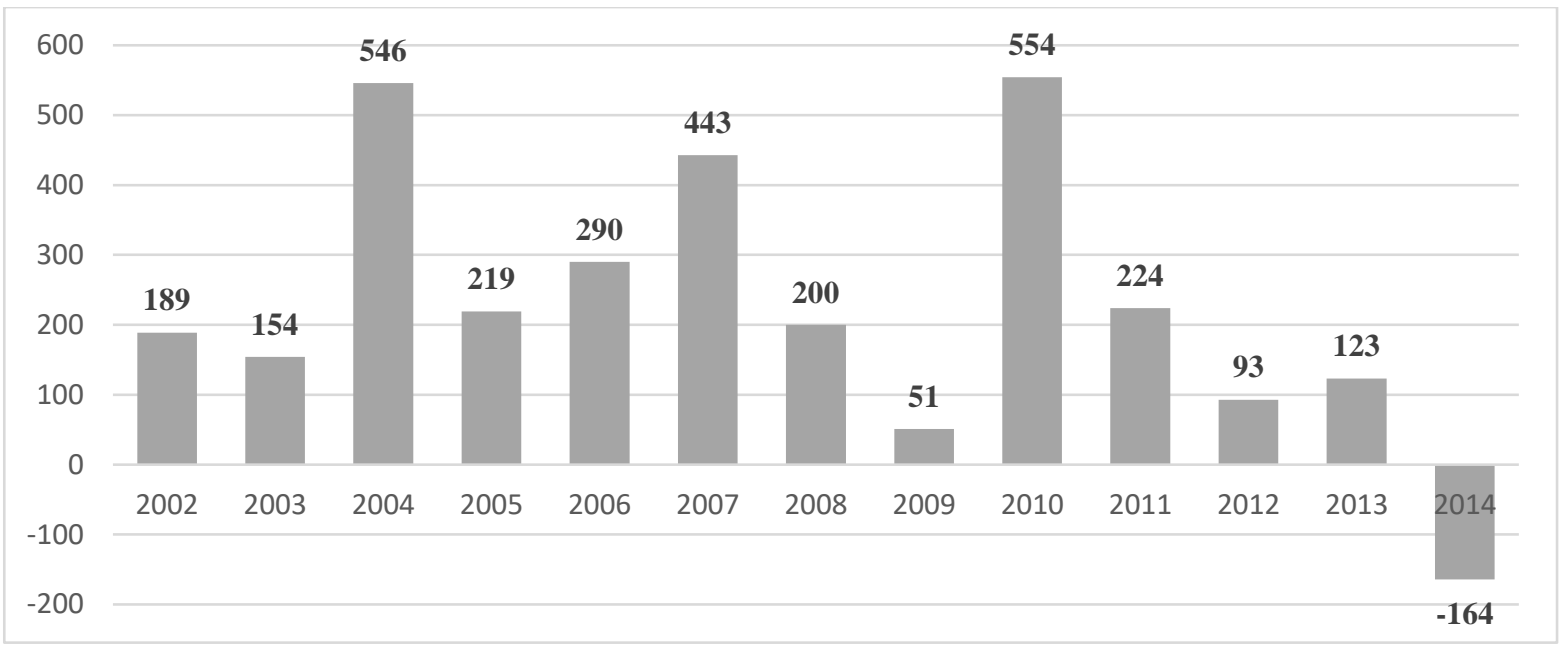

Fonte: FIESP (2015)

Rowthorn e Ramaswany (1999) explicam que a perda de participação do emprego industrial no emprego total de um país, pode ser considerada como uma consequência da desindustrialização. Mais tarde, Tragenna (2009) de forma mais ampla apresenta o conceito de desindustrialização, como sendo uma ocorrência em que tanto o emprego industrial, quanto o valor adicionado da indústria se reduzem como proporção do emprego total e do PIB, respectivamente. Desta forma, diante dos dados acima, pode-se verificar uma desindustrialização brasileira ocorrida nos últimos anos, em que a indústria de transformação reduziu sua participação tanto na participação do emprego quanto em proporção do PIB brasileiro.

Neste sentido, os pesquisadores Carvalho e Silva (2005), Palma (2005; 2014), Rajan e Subramanian (2009), Bresser-Pereira (2012; 2015), Bacha (2013), Marconi e Rocha (2012), Bonelli, Pessoa e Matos (2013), Lazzarini, Jank e Inoue (2013), Werneck (2013) e Oreiro e 
Marconi (2014) passaram a estudar a desindustrialização ocorrida no Brasil, com o objetivo de desvendar as possíveis causas, como também sugerir medidas para neutralizar os efeitos negativos desse fenômeno, que podem prejudicar o crescimento da economia brasileira.

Conforme Palma (2005) ocorre no Brasil uma desindustrialização "prematura", em consequência de uma profunda mudança da política de substituição de importações em função do Consenso de Washington, que a partir da década de 1990, culminou numa liberalização comercial e financeira, sem que o país alcançasse um determinado nível de renda per capita, como processo normal de seu desenvolvimento.

Dessa forma, a desindustrialização quando em transição natural, pode ser positiva para economia, o que não ocorreu no caso do Brasil, sendo ela resultado de uma realocação de trabalho desde a fabricação até serviços, através da terceirização de atividades como limpeza, segurança, restauração e processamento de dados; resultado de uma redução da elasticidaderenda para os fabricantes; consequência de um maior crescimento da produtividade da indústria; resultado de uma nova divisão internacional do trabalho, o que reduz o nível de emprego nos países industrializados, especialmente para os que não possuem mão de obra qualificada (PALMA, 2014).

Marconi e Rocha (2012) explicam essa transição, ao analisar a renda per capita e a participação da manufatura no valor adicionado para países selecionados, conforme dados da Figura 1. Dessa forma, é possível verificar que a desindustrialização brasileira ocorre em um estágio de desenvolvimento bem menor do que aquele alcançado pelos países desenvolvidos selecionados.

Figura 1 - Renda per capita e participação da manufatura no valor adicionado (19502005; exceto ex-Alemanha Ocidental, de 1950 a 1991)

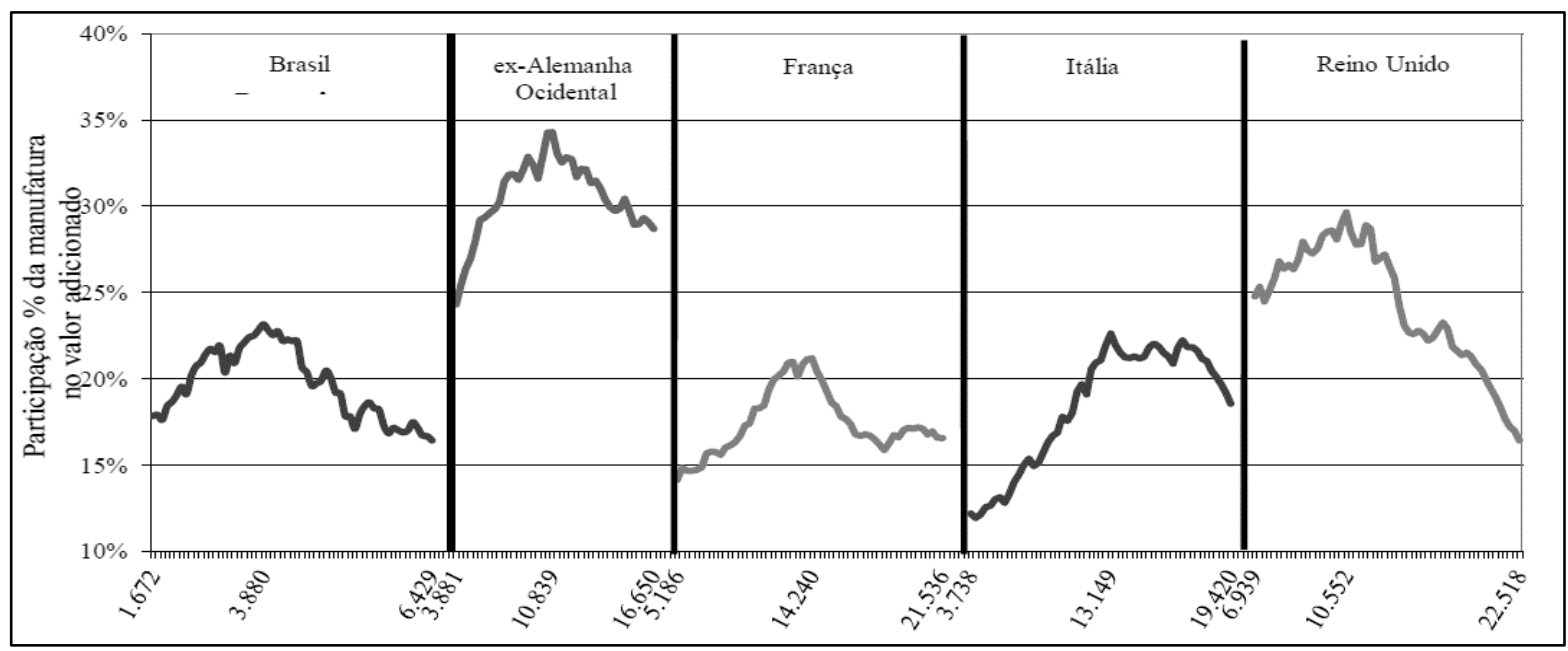


Fonte: Marconi e Rocha (2015, p. 869)

Mesmo quando comparado com países emergentes (Argentina, México, Coréia, Malásia e Tailândia), a transição para a economia brasileira apresentou o nível de renda per capita mais baixo entre os países analisados. É possível que a sobreapreciação da taxa de câmbio real explique uma parte dessa dinâmica nos países emergentes ocorrida de forma precoce, em virtude do impacto negativo sobre a demanda agregada, produção e, consequentemente, sobre a estrutura produtiva da economia. (MARCONI e ROCHA, 2012).

Além disso, os autores Carvalho e Kupfer (2007) também atribuem a desindustrialização ocorrida nos últimos anos, a uma transição da indústria brasileira passando de uma indústria com estrutura diversificada, para uma estrutura de especialização produtiva, porém a fase de diversificação da estrutura indústria brasileira terminou mais cedo em termos de seu processo de desenvolvimento do que ocorreu em outros países (Austrália, Canadá, EUA, Taiwan e Coréia), como resultado a indústria passou a especializar em favor de setores com menor conteúdo tecnológico, como o de commodities.

Outro aspecto a destacar é o fenômeno Dutch Disease, defendido por Bresser-Pereira, ex-ministro da fazenda, como principal causa da desindustrialização brasileira. Para o autor, a Dutch Disease, é uma falha de mercado, em decorrência da existência abundante de recursos naturais levando o país a se especializar na produção e exportação destes bens ou serviços. Estes, quando exportados, atraem divisas externas, que por sua vez, apreciam a moeda nacional e isso prejudica as exportações das indústrias, que não contam com vantagens de custos em relação aos concorrentes internacionais, como a produção de commodities do país, e assim necessitariam de uma taxa de câmbio mais competitiva para garantir uma rentabilidade no comércio internacional (BRESSER-PEREIRA, 2012).

Diante disso, Bresser-Pereira (2015), sugere como medidas para neutralizar a Dutch Disease, o mecanismo de "equilíbrio industrial", pelo qual o governo pode estabelecer um imposto sobre as exportações de commodities, que deve ser igual à gravidade da Dutch Disease, contudo, apesar de ser necessária, é politicamente inviável, devido aos possíveis conflitos com os grupos de interesse. Neste sentido, como uma alternativa second best, o autor sugere, aplicar tarifa de importação composta por duas partes: uma "tarifa-câmbio" destinada a neutralizar a Dutch Disease e uma "tarifa-escalonamento" para dar conta da política universalmente adotada de se estabelecerem tarifas mais altas para os bens com maior valor adicionado per capita, tratase de uma solução inferior à do imposto, porque só neutraliza a Dutch Disease para efeito de mercado interno. 
Oreiro e Marconi (2014) compartilham o mesmo pensamento sobre a desindustrialização brasileira, atrelando-a à sobrevalorização da taxa de câmbio ocorrida nos últimos anos, embora o crescimento dos salários reais a frente da produtividade do trabalho pós-2008 tenha contribuído para acelerar esse processo. Segundo os autores, a baixa produtividade do trabalho na indústria de transformação é resultado de baixos investimentos feitos na ampliação e modernização da capacidade produtiva, o primeiro devido à combinação do câmbio sobrevalorizado o segundo diante do juro real alto.

Bacha (2013) explica que o Brasil presenciou entre o período de 2005 a 2011 um processo de crescimento, consequência da bonança externa (entrada de capitais estrangeiros e um aumento dos preços de suas exportações de commodities) e em função disso a indústria de transformação perdeu participação no PIB. Ou seja, a indústria brasileira teria sido sim afetada pela chamada Dutch Disease, reiterando mais uma vez o conceito de uma valorização da taxa de câmbio real provocada pela melhoria das relações de troca de commodities e o aumento da transferência de recursos financeiros do exterior.

Carvalho e Silva (2005) chamam atenção para a vulnerabilidade do comércio dos produtos primários em comparação com os produtos industrializados. Para os pesquisadores o setor de produtos primários indica um declínio no comércio mundial, pois a taxa de crescimento das importações agrícolas mundiais é bem menor que a dos demais produtos. Ainda afirmam que as exportações brasileiras mais crescem para os mercados dos países em desenvolvimento, que nem sempre têm capacidade sustentada de pagamentos.

Rajan e Subramanian (2009) analisam os efeitos sobre as taxas de crescimento da indústria com relação ao que parecem fluir em grande parte através das taxas de câmbio reais. Os pesquisadores utilizam a hipótese de que o apoio aos influxos pode reduzir a competitividade dos setores industriais comercializáveis. Eles concluem que países com taxas de câmbio mais apreciado, tem afetado negativamente, as exportações de setores industriais comercializáveis.

Bonelli, Pessoa e Matos (2013) atribuem ao fenômeno desindustrialização no Brasil há três dimensões inter-relacionadas: a primeira, de caráter cíclico, tem a ver com o fraco desempenho da indústria em nível global; a segunda, atribui importância à integração da China, da Índia e de outros países orientais de renda baixa à economia mundial, integração essa que mudou o quadro das vantagens comparativas globais com implicações não triviais para o desempenho da indústria em vários países pela concorrência das importações; uma terceira, estrutural como a anterior, é a tendência secular de perda de peso da indústria no mundo que resulta da mudança nos padrões de consumo que acompanha o processo de crescimento econômico, em que as atividades do setor de serviços ganham peso em relação às industriais. 
Neste sentido, pode-se observar no Gráfico 7, o grau de industrialização médio por grupo de países medido pela participação da indústria no PIB a preços correntes de 1970 a 2010. Com exceção da Ásia, impulsionado pelo vigor chinês, os demais grupos de países apresentaram uma perda de participação da indústria no PIB ou, na melhor das hipóteses, mantiveram a participação, podendo constatar que a desindustrialização ocorrida no Brasil não é fenômeno estritamente nacional, mas está diretamente relacionada a desindustrialização que está ocorrendo no mundo, em função do crescimento das economias dos países.

\section{Gráfico 7 - Grau de industrialização médio por grupos de países, 1970-2010 em \%}

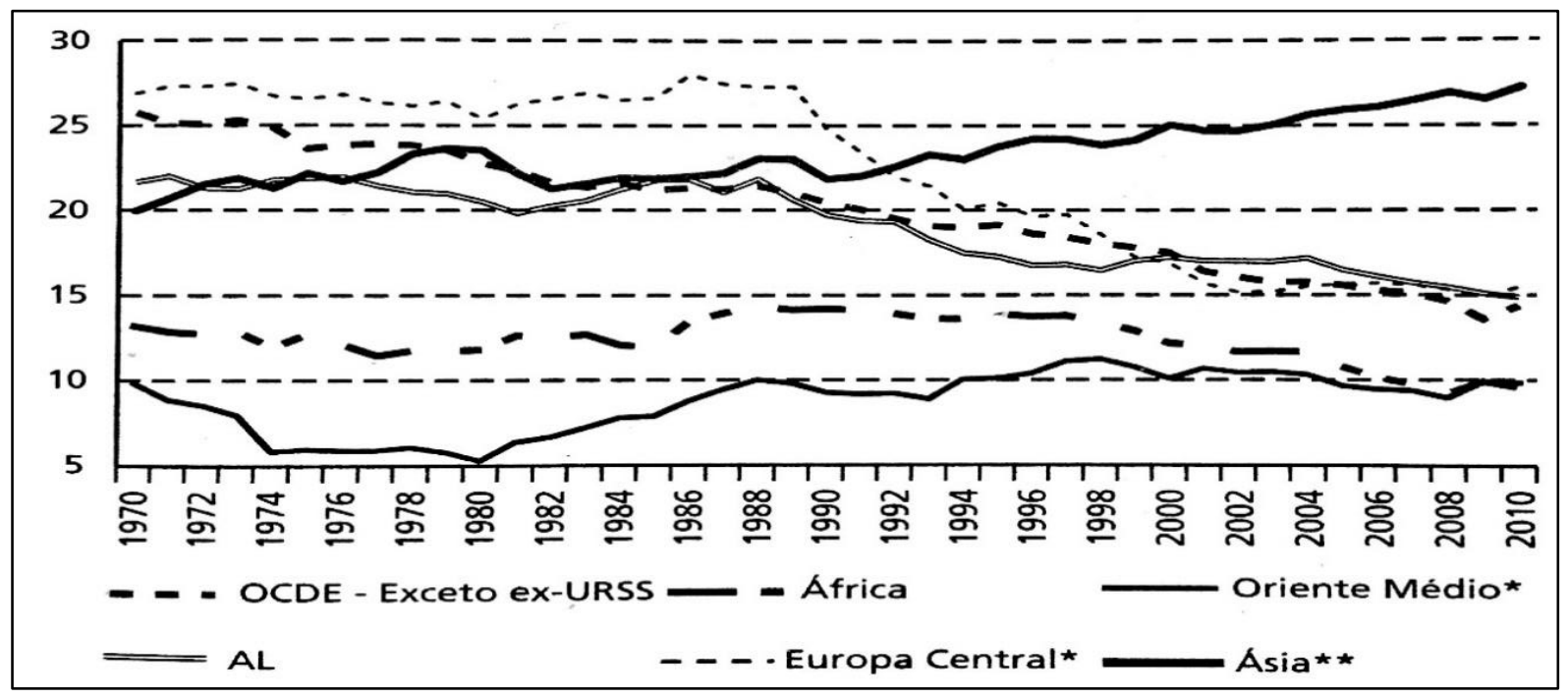

Fonte: Bonelli, Pessoa e Matos (2013, p. 55)

Por outro lado, Lazzarini, Jank e Inoue (2013), salientam que o problema da indústria brasileira estaria relacionado ao baixo crescimento da produtividade em comparação com o resto do mundo. Para os pesquisadores, muitos seguimentos industriais simplesmente não conseguiram suportar a pressão competitiva das economias emergentes do sudeste da Ásia, mais produtivas e eficientes.

Neste contexto, para que a indústria brasileira volte a crescer é importante haver investimentos em pesquisa e inovação, com objetivo de obter ganhos de produtividade, pois por essa via, é possível que as empresas consigam obter economias de escala, ou seja, máxima utilização dos fatores produtivos envolvidos, com ganhos de eficiência na produção e, além disso, que possam estimular a criação e desenvolvimento de novos produtos. Contudo, o que se observa é que esse perfil inovador não é presente na maioria das indústrias do país, conforme a Pesquisa de Inovação Tecnológica realizada pelo IBGE (2010) no período de 2006 a 2008, que 
obteve como amostra um total de 100,5 mil indústrias, apresentou que apenas 38,1\% foram inovadoras, percentual inferior ao observado nos setor de serviços, cuja taxa foi de 46,2\%.

É importante ressaltar que a globalização tem pressionado cada vez mais as empresas por constantes transformações na busca de novos métodos e novas formas de transacionar suas mercadorias, incessantemente pela busca de reduzir os seus custos e gerar competitividade frente ao mercado cada vez mais globalizado e acirrado. As constantes transformações como a abertura comercial e financeira, a difusão da informação, a terceirização das atividades, a cadeia de fornecimento, internacionalização das empresas e mais recentemente a cadeia global de valor, são algumas das mudanças que impactaram profundamente as empresas e, consequentemente, os países que precisam entender esse contex to e inserir-se, como alternativa para o crescimento econômico.

Neste sentido, o papel do setor privado em busca pela produtividade, deve ser acompanhado por um ambiente macroeconômico, propiciado pelo Estado, que estimule os investimentos necessários para que a indústria possa crescer. Observa-se que o início da industrialização brasileira foi acompanhado por uma forte política de substituição das importações, com a globalização forçando os países a praticarem políticas liberais, forçou as empresas a inserir-se num ambiente cada vez mais competitivo.

Contudo, a transição pela qual a indústria brasileira passou a partir da década de 90 , pode ser considerada de forma predatória, uma vez que, ao abrir a economia, as indústrias não estavam preparadas para tamanha abertura, mesmo que o governo Collor tivesse criado uma política industrial com a finalidade de amenizar os efeitos da abertura, entretanto, os objetivos se perderam diante das reformas vivenciadas no período. Em contraponto a isso, uma política cambial sobrevalorizada a partir de 2003, com o governo Lula, impactaram diretamente à indústria, uma vez que, estimulou as importações de produtos industriais. Mesmo que a o governo Dilma, tenha praticado depreciação do câmbio, contudo, ainda não surtiu efeito e ao final de 2014, a balança comercial apresentou déficit após 13 anos de balança positiva, sendo os produtos industriais responsáveis por $79 \%$ das importações, pode ser que a médio ou longo prazo a depreciação da moeda para frear as importações possa surtir efeitos e diante deste cenário estimule a indústria local às exportações.

\section{CONSIDERAÇÕES FINAIS}

A reestruturação da economia brasileira a partir dos anos 90, principalmente diante da liberalização comercial e financeira, impactou diretamente nas indústrias nacionais que não 
estavam preparadas para tamanha abertura econômica. Combinado com política cambial apreciada a partir dos anos 2000, afetaram de forma desproporcional o desempenho da indústria brasileira, como consequência da especialização na vantagem comparativa do país para produção e exportação de commodities, causando o fenômeno Doença holandesa no Brasil.

Diante do ambiente macroeconômico desfavorável, a indústria não obteve crescimento de produtividade em decorrência dos baixos investimentos feitos na ampliação e modernização da capacidade produtiva. Como resultado, pode-se constatar que a indústria brasileira está se desindustrializando, como perda de participação no PIB brasileiro. É evidente uma queda da indústria de transformação na geração de emprego e renda, impondo profundas limitações para o crescimento econômico do país.

Com relação as exportações do setor, diante do câmbio apreciado, a indústria passou a direcionar sua produção para o mercado interno, mas ao longo do período se pode verificar que as indústrias também tem perdido espaço no mercado interno, uma vez que as importações de produtos industriais cresceram significativamente, colocando em risco o desempenho do setor industrial.

Por último, vale salientar, para que haja investimento, se faz necessário o lucro, se o câmbio apreciado pressiona os preços para baixos e reduz as margens de lucros, como estimular os investimentos para o setor industrial? Diante disso, é importante o papel do Estado em atuar na política cambial, possibilitando uma taxa de câmbio que neutralize a apreciação cambial, para que possa estimular os investimentos tão esperados para o crescimento do setor. Foi possível observar que o governo Dilma depreciou a moeda nos últimos meses de 2014, porém ainda sem reflexos para o desenvolvimento da indústria brasileira.

\section{REFERÊNCIAS BIBLIOGRÁFICAS}

BAUMANN, E.; CANUTO, O.; GONÇALVES, R (2004). Economia internacional: teoria e experiência brasileira. Rio de Janeiro: Elsevier.

\section{BANCO CENTRAL DO BRASIL - BACEN (2014). Funções do Banco Central do Brasil.}

Disponível em: < http://www4.bcb.gov.br/pec/gci/port/focus/FAQ\%2011-

Fun\%C3\%A7\%C3\%B5es\%20do\%20Banco\%20Central\%20do\%20Brasil.pdf> Acesso em: 06 dez. 2014. 
BATISTA, P. N (1994). O Consenso de Washington: A visão neoliberal dos problemas latino-americanos, Caderno Dívida Externa nº 6, $2^{\circ}$ ed., PEDEX, São Paulo.

BACHA, E (2013). Bonança externa e desindustrialização: uma análise do período 20052011. In: BACHA, E.; BOLLE, M. B. (Org.). O futuro da indústria no Brasil: desindustrialização em debate. Rio de Janeiro: Civilização Brasileira, p. 97-120.

BAHRY, T. R.; PORCILE, G (2014). Os ciclos de endividamento da economia brasileira no período 1968-1999. Revista de Economia Contemporânea, IE UFRJ, v. 8, n.1, p. 05-32.

BRESSER-PEREIRA, L. C (1990) A crise da América Latina: Consenso de Washington ou crise fiscal?. Pesquisa e Planejamento Econômico (Rio de Janeiro), v. 21, p. 3.

BRESSER-PEREIRA, L. C (2012).A taxa de câmbio no centro da teoria do desenvolvimento. Estud. av. [online]. vol.26, n.75, pp. 7-28.

BRESSER-PEREIRA, L. C (2015). A quase estagnação brasileira e sua explicação novodesenvolvimentista. Disponível em: <http://www.bresserpereira.org.br/papers/2015/332Quase-estagna\%C3\%A7\%C3\%A3o-Nelson-Fevereiro-2015.pdf> Acesso em: 24 fev. 2015

BONELLI, R. PINHEIRO, A. M. R. C (2012). Competitividade e Desempenho Industrial: Além do Câmbio. Rumo ao Brasil Desenvolvido. 1ed. Rio de Janeiro: José Olympio, v. 1, p. $3-248$.

BONELLI, R.; PESSOA, S.; MATOS, S (2013). Desindustrialização no Brasil: fatos e interpretação. In: BACHA, E.; BOLLE, M. B. (Org.) O futuro da indústria no Brasil: desindustrialização em debate. Rio de Janeiro: Civilização Brasileira, p. 201-225.

CAPACLE CORREA, V. H.; LIMA, F (2006). Política Cambial Como Instrumento de Estabilização Econômica. Revista de Negócios Internacionais (UNIMEP), UnimepPiracicaba-SP, n.3, p. 31-37.

CAMPOS, A. F (1997) O processo de privatização: o caso da Petrobrás. In: Revista Interface. Vitória. Ano II, no 3 . 
CAMPOS, A. F (1999) O II PND e o processo de estatização da dívida externa: a crise das estatais e a sua posterior privatização. Revista Raízes, Paraíba, p. 49-64.

CARVALHO, M. A.; SILVA, C. R. L (2005). Vulnerabilidade do comércio agrícola brasileiro. Rev. Econ. Sociol. Rural [online]. vol. 43, n.1, p. 9-28.

CARVALHO, L. B.; KUPFER, D (2007). A Transição Estrutural da Indústria Brasileira: Da diversificação para a especialização. In: XXXV Encontro Nacional de Economia da ANPEC, 2007, Recife. Anais do XXXV Encontro Nacional de Economia da ANPEC.

CARNEIRO, F. L (2013). A influência da taxa de câmbio sobre o desempenho comercial. 2013. 140 f. Dissertação (Mestrado em Economia) - Universidade de Brasília - UnB.

DAVIDOFF CRUZ, P (1982). A Dívida Externa Brasileira. In: BELUZZO, L. G. E COUTINHO, R. (Org.) Desenvolvimento Capitalista no Brasil: ensaios sobre a crise. Vol. 2. São Paulo: Brasiliense.

INSTITUTO BRASILEIRA DE GEOGRAFIA E ESTATÍSTICA - IBGE (2011). Pesquisa industrial anual. Disponível em:

<<http://www.ibge.gov.br/home/estatistica/economia/industria/pia/empresas/2012/defaultemp resa.shtm>. Acesso em: 03 dez. 2014.

FONSECA, R (2012). Produtividade e crescimento da indústria brasileira. Revista Brasileira de Comércio Exterior, v. 26, p. 42-51.

FIESP - Federação das Indústrias do Estado de São Paulo (2015). A importância da indústria de transformação na ótica do emprego. Disponível em: <file://C:/Users/usuario/Dropbox/Documentos\%202014/Disserta\%C3\%A7\%C3\%A3o/Orien nta\%C3\%A7\%C3\%B5es/12\%20orienta\%C3\%A7\%C3\%A3o/CAP\%C3\%8DTULOS/Desindu strializa\%C3\%A7\%C3\%A3o/a-importancia-da-it-no-emprego_6163.pdf> Acesso em: 10 fev. 2015

FONSECA, P. C. D (2009). O Processo de Substituição de Importações. São Paulo. 
FURTADO, C (2003). Formação econômica do Brasil. 32 ed. São Paulo: Nacional.

GENNARI, A. M (2001). Globalização e a Nova Estratégia de Acumulação Capitalista sob a Hegemonia Neoliberal no Brasil nos Anos 90. Anais do XIV Congresso Brasileiro de Economia, Recife - PE.

INSTITUTO DE PESQUISA ECONÔMICA APLICADA - IPEA (2013). Radar: tecnologia, produção e comércio exterior. Brasília: Ipea.

LAZZARINI, S. G.; JANK, M. S.; INOUE, C. F. K (2013). Commodities no Brasil: maldição ou bênção? In: BACHA, E.; BOLLE, M. B. (Org.). O futuro da indústria no Brasil: desindustrialização em debate. Rio de Janeiro: Civilização Brasileira, p. 201-225.

MARCONI, N.; ROCHA, M (2012). Taxa de câmbio, comércio exterior e desindustrialização precoce: o caso brasileiro. Economia e Sociedade (UNICAMP. Impresso), v. 21, p. 853-888.

OREIRO, J. L.; MARCONI, N (2014). Teses equivocadas no debate sobre desindustrialização e perda de competitividade da indústria brasileira. Revista NECAT, v. 3, p. 24-48.

PALMA, J. G (2014). De-industrialisation, 'premature' de-industrialisation and the dutch-disease. Revista NECAT, v.3, p. 7-23.

PALMA, J. G (2005). Four sources of de-industrialisation and a new concept of the Dutch-Disease In: CAMPO, J. A. (ed.) Beyond Reforms: structural dynamic and macroeconomic vulnerability, Stanford University Press and the World Bank.

PINHEIRO, A. C (1999). Privatização no Brasil: Por quê? Até onde? Até quando? In: GIAMBIAGI, F.; MOREIRA, M. M. (Org.). A economia brasileira nos anos 90. Rio de Janeiro: BNDES, p. 11-42. 
PINHEIRO, A. C.; GIAMBIAGI, F.; GOSTKORZEWICZ (1999). O Desempenho

Macroeconômico do Brasil nos Anos 90. In: GIAMBIAGI, F.; MOREIRA, M. M. (Org.). A economia brasileira nos anos 90. Rio de Janeiro: BNDES, p. 11-42.

ROWTHORN, R; RAMASWANY, R (1999). Growth, Trade and Deindustrialization. IMF Staff Papers, vol. 46, N.1.

RAJAN, R. G.; SUBRAMANIAN, A (2009). Aid, Dutch Disease, and Manufacturing Growth.Disponível em:<http://dspace.cigilibrary.org/jspui/bitstream/1234 56789/27919/1/WP\%20196\%20\%20Aid\%20Dutch\%20disease\%20and\%20manufacturing\%2 0growth.pdf?1>. Acesso em: 06 Set. 2013.

SILVA, M. L. F (2002). Plano Real e Ancora Cambial. Revista de Economia Política, São Paulo, v. 22, n.3, p. 3-24.

SOARES, S. S. S (2008). Instituições e Privatização: uma análise do programa brasileiro de desestatização. Gestão e sociedade (UFMG), v. 2, p. 570-610.

SOARES, F. A. R.; PINTO, M. B. P (2008). Desequilíbrios cambiais e os fundamentos econômicos: uma análise do Plano Real. Rev. econ. contemp. [online]. vol.12, n.1, pp. 5-40.

SOARES, F. A. R (2006). A administração da taxa de câmbio no plano real e os fundamentos econômicos brasileiros. $174 \mathrm{f}$. Tese (Doutorado em Economia) - Faculdade de Economia, Administração, Contabilidade e Ciência da Informação e Documentação, Universidade de Brasília.

SUZIGAN, W. (1978.). Indústria: política, instituições e desenvolvimento. Rio de Janeiro: IPEA/INPES.

TREGENNA, F (2009). Characterizing deindustrialization: an analysis of changes in manufacturing employment and output internationally. Cambridge Journal of Economics, Vol. 33. 
TREVISAN, A. L (2004). A Política Cambial Brasileira durante a Vigência do Acordo de Bretton Woods: 1945-1973.160 f. Dissertação (Mestrado em Economia) - Universidade Federal do Rio Grande do Sul.

VELOSO, F. A.; VILLELA, A.; GIAMBIAGI, F (2008). Determinantes do "milagre" econômico brasileiro (1968-1973): uma análise empírica. Rev. Bras. Econ. [online]. vol.62, n.2, pp. 221-246.

WERNECK, R. L. F (2013). Abertura, competitividade e desoneração fisscal. In: Edmar Bacha e Monica de Bolle. (Org.). O futuro da indústria no Brasil. 1ed. Rio de Janeiro: Civilização Brasileira, v. 1, p. 373-392.

KODJA, C (2009). Crise econômica ao final do século XX - 1970 a 2000: advento de uma nova organização social e financeira. 259 f. Tese (Doutorado em História Econômica) Faculdade de Filosofia, Letras e Ciências Humanas, Universidade de São Paulo.

KRUGMAN, P.; OBSTFELD, M (2001). Economia internacional: teoria e prática. São Paulo: Pearson Education do Brasil.

KUPFER, D (1998). Trajetórias de Reestruturação na Indústria Brasileira.185f. Tese (Doutorado em Economia) - Universidade Federal do Rio de Janeiro. 